Levinson, Jerrold (1982). 'Music and Negative Emotion', reprinted in id., Music, Art, and Metaphysics: Essays in Philosophical Aesthetics (Ithaca and London Cornell UP, 1990), 306-335.

Levinson, Jerrold (1997). 'Emotion in Response to Art', reprinted in id. Contemplating Art (Oxford: Clarendon Press, 2006), 38-55.

Morreall, J. (1985). 'Enjoying Negative Emotions in Fictions', Philosophy and Literature 9(1): 95-103.

Robinson, Jenefer (1995). 'L'education sentimentale', Australasian Journal of Philosophy 73(2): 212-226.

Scruton, Roger (1999). The Aesthetics of Music (Oxford: Oxford UP).

Smuts, Aaron (2009). 'Art and Negative Affect', Philosophy Compass 4(1): 39-55 (Blackwell Online).

Walton, Kendall (1990). Mimesis as Make-Believe: On the Foundations of the Representational Arts (Cambridge, MA: Harvard UP).

Williamson, Timothy (2002). Knowledge and Its Limits (Oxford: Oxford UP).

\section{Painful Art and the Limits of Well-Being}

Aaron Smuts

In this chapter I ask what painful art can teach us about the nature and importance of human welfare. My goal is not so much to defend a new solution to the paradox of tragedy as it is to explore the implications of the kinds of solutions that I find attractive. Both nonhedonic compensatory theories and constitutive theories plausibly explain why people seek out painful art, but they have troublesome implications. On some narrow theories of well-being, they imply that painful art is bad for us. Accordingly, we may rightly wonder if it is rational for people to watch melodramas or to listen to love songs. One might think that we should generally avoid unpleasant works of art. This implication flirts with absurdity. I show how it can be avoided by making a distinction between well-being and worth.

\subsection{Introduction}

Why do we listen to love songs, watch melodramas, or engage with any of the wide variety of works of art that tend to arouse unpleasant, or even downright painful, emotional reactions? This question captures what is known as the paradox of tragedy, or, more generally, the paradox of painful art: we tend to avoid situations that arouse negative emotions, yet we seek out art that we know is likely to elicit such feelings. This is puzzling.

Some think the puzzle can be resolved by appealing to the various pleasures to be had from putatively painful art. We take pleasure from a well-crafted narrative, beautiful prose, a melodious tune, and skilled acting. One might plausibly suggest that these pleasures compensate for the pain of the negative emotions. Call this style of solution to the paradox the hedonic compensatory theory (HCT), since it holds that 
the pain is compensated for hedonically. I will argue that HCT is an inadequate solution to the paradox. The principal problem is that HCT does not jibe with the phenomenology: people typically, or at least frequently, describe their experiences of the kinds of works in question as, on the whole, painful, distressing, gut-wrenching, and emotionally devastating, not as on balance pleasurable.

Nonhedonic compensatory theories (NHCT) are more plausible than their hedonic counterparts. NHCT holds that there are other kinds of value to be had from painful art that compensate for the unpleasantness. Although NHCT is more plausible, I think it fails to account for the fact that the painful experiences are often intrinsically valuable. Of course, this is a controversial suggestion. Regardless of whether painful experiences can be intrinsically valuable, I will argue that they are plausibly constitutive of kinds of value that motivate audiences to appreciate many painful works of art. Call this style of solution a constitutive theory (CT).

Although I defend a constitutive solution to the paradox of tragedy my chief goal here is to explore the implications of the solutions I find most attractive, namely, those that do not appeal to hedonic compensation. ${ }^{1}$ Both nonhedonic compensatory theories and constitutive theories explain why audiences pursue painful art, but they raise further questions. If the pain experienced in response to a work is not hedonically compensated for, then on some plausible theories of well-being it appears that the work might be bad for audiences. If so, one might suggest, it is irrational for people to watch melodramas or listen to love songs. Accordingly, we should generally avoid love songs, melodrama tragedy, conspiracy thrillers, maybe even horror movies, and should encourage our loved ones to likewise avoid them.

Herein lies a problem: If a solution to the paradox of painful art leads one to the conclusion that much of the history of literature, film, and popular music is bad for audiences, that we are irrational to pursue a wide variety of seemingly innocuous works, and that we have excellent reason to discourage others from watching melodramas or listening to love songs, then something has gone terribly wrong. As Chisholm suggests, if we are forced to choose between an obvious truth and a controversial philosophical theory (such as NHCT or CT), we should reject the theory. ${ }^{2}$ We should reject the theory first and figure out where it went wrong later.

Happily, there is another option: neither NHCT nor CT alone implies the absurdity that we are irrational in our pursuit of painful art. The charge of irrationality follows only if we also accept a narrow theory of well-being, such as hedonism - the view that pleasure and pain are the only things that are ultimately good or bad for a person. Hence, rather than a problem for NHCT and CT, it appears that we have the seed of an important objection to hedonism about welfare and its ilk. If hedonism implies that painful art is bad for us and that we are irrational to attend to such works, we should reject hedonism and any other theory with similar implications.

Although it appears that we must either defend a hedonic compensatory solution to the paradox of painful art or defend a wide theory of well-being, I argue that this is not the case. We can accept both CT, a nonhedonic compensatory theory, and a narrow theory of well-being without courting absurdities. I offer a brief defence of both views and show that that putative problem is the product of a mistaken assumption about the importance of well-being. But my conclusion is nevertheless controversial. I conclude that although it might be rational to pursue painful art, it is sometimes prudentially bad.

So far I have only provided a brief sketch of the dialectic. In what follows I will fill in the details. My argument proceeds in a few steps. First, I argue against hedonic compensatory solutions to the paradox. Then I provide a brief defence of CT. Before showing how this leads to the problem sketched above, I provide an overview of the leading theories of well-being. I then present the problem and briefly defend a narrow theory of well-being. Finally I suggest that well-being is of limited importance. Rather than focus on the welfare impact of painful art, we should be concerned with how it affects the worth of our lives. I argue that the value had from painful art often makes our lives more worth living, despite sometimes having an adverse effect on our welfare.

\subsection{The paradox of painful art}

Most of the literature on the paradox of tragedy is concerned with a motivational question: What motivates audiences to pursue works of art that arouse negative emotional responses? ${ }^{3}$ The motivational question is seldom stated in the same way, and it is rarely shown to be a formal paradox. Depending on how one poses the question, different solutions drop out. As it is typically stated, the paradox of tragedy asks how it is possible for audiences to feel pleasure in response to the fictional portrayal of events in a tragedy, or else to other distressing, depressing, and unpleasant works of art. But this formulation of the issue begs a central question: Do tragedies afford, on balance, pleasurable experiences? Perhaps they do. But even if tragedies are generally pleasurable, 
there are certainly works in other genres, such as melodrama, that do not typically provide experiences that are, on balance, pleasurable.

The puzzle encompasses far more than mere tragedy. The breadth of negative emotional experiences to which audiences willingly submit themselves is extensive. For starters, a great deal of religious-themed art in the Western tradition seeks to provoke painful emotional reactions via depictions of the suffering of Christ and the martyrdom of saints. The motivation for viewing religious works is complicated. We need not settle the issue here, as there are plenty of clear secular cases. For instance, consider the genre of melodrama. A popular cinematic melodrama based on an Alice Munro story, Away from Her (Sarah Polley 2006), features a couple torn apart by past infidelity, uncovered paradoxically by the loss of recent memories from Alzheimer's. Just a month into her stay at a nursing home, the wife falls in love with another resident and all but forgets her husband; invariably, audiences weep and weep. This is far from aberrant. Another exemplary cinematic melodrama, Plenty (Schepisi 1985) ends with a flashback scene, where in the summer of her youth, the protagonist projects forward: 'There will be days and days like this.' But after two hours watching the heroine go insane from boredom in a stultifying marriage, the audience knows better. For susceptible viewers, good melodramas elicit visceral sorrow. On any plausible account, a melodrama that fails to jerk tears is a failed melodrama.

Likewise, the horror genre primarily attempts to arouse a combination of two aversive responses, fear and disgust, yet many people routinely attend horror movies where such responses are almost guaranteed. Although I think that the unpleasantness of fear and non-olfactory disgust is exaggerated, some works in the horror genre inspire unpleasant dread and profound sadness. Nicolas Roeg's beautiful and profoundly depressing masterpiece Don't Look Now (1973) denies its main character hope that the universe is anything but indifferent to human happiness. Conspiratorial fictions such as The Parallax View (Pakula 1974) often leave audiences without clear explanations of the events other than that the world is a malevolent cauldron of corruption, where almost anyone could become an expendable tool of powerful interests. Melancholy music can arouse remorse at past wrongs or missed opportunities and acutely felt nostalgia, where listeners come to desire to return to previous times and suffer from the realization that this desire can never be satisfied. ${ }^{5}$ There is no denying that much good art hurts.

When one looks beyond tragedy and notices the array of art that arouses negative emotions, the puzzle becomes more pronounced. In response to art, people seem far more willing than in ordinary life to experience emotions that we think of as negative. We describe an emotion as negative when it is typically accompanied by an aversive reaction. Accordingly, we typically avoid situations that arouse the emotion. In addition, such emotions are often described as having a negative affect; they feel bad. We might say that they have a negative hedonic tone. ${ }^{6}$ The emotions themselves are thought to be an important source of aversion. In some cases, such as those of profound sadness, we would go so far as to say that the emotions are painful. ${ }^{7}$ This is precisely why I refer to the issue as the paradox of painful art. The paradox boils down to a simple question: If people want to avoid pain, then why do they want to experience art that is painful?

The paradox of painful art can be formalized as follows:

1. People voluntarily avoid things that provide painful experiences and only pursue things that provide pleasurable experiences.

2. Audiences routinely have net painful experiences in response to putatively painful art (PPA), such as tragedies, melodramas, religious works, sad songs, and horror films.

3. People expect to have net painful experiences in response to PPA.

4. People voluntarily pursue works that they know to be PPA.

The fourth claim, that people voluntarily pursue putatively painful art, is beyond reasonable doubt. It is clear that audiences are not typically forced to the movies against their will. There is no Hollywood secret police force gathering people from their homes, forcing them into buses, only to be made to sit in crowded theatres while eating buckets of popcorn. And, as the third claim makes explicit, it is clear that audiences know what they are getting into. Rare is it that people go to movies without first reading reviews, seeing a preview, or talking to friends. Theatres do not have to employ bait-and-switch tactics to get audiences to watch melodramas. There is no need to advertise a comedy to get audiences to buy tickets to a tearjerker. Hence, no one has taken issue with the fourth claim of the paradox: audiences willingly seek out putatively painful art with largely accurate expectations about what they will experience.

In contrast, nearly every solution to the paradox has rejected the second claim, as I have formulated it - that people have net painful experiences in response to putatively painful art. There are two broad options here. One might simply deny that putatively painful art provides any noteworthy painful experiences. Alternatively, one might deny that the experiences are on the whole painful. Although some take the first option, most take the second, more popular route; they claim that the 
pain is compensated for by other pleasures. Although there are nonhedonic compensatory solutions in the literature, these are atypical. Commonly, compensatory solutions to the paradox claim that there is hedonic compensation. They admit that audiences feel pain in response to putatively painful art, but they claim that the works of art provide adequate compensation in the form of other pleasures.

The second claim of the paradox has been a popular target, though upon reflection it appears to be secure. I suspect that critics of the second premise have simply failed to adequately consider the phenomenology of painful art experiences, a phenomenology that provides a great deal of data in support of the second claim. I can think of a few reasons why this error is so pervasive, but one stands out: ${ }^{9}$ the failure to take the phenomenology of painful art seriously is likely the product of a crude, implicit assumption of a relatively strong form of motivational hedonism. This assumption makes it difficult to see that the experience of some art might not be on the whole pleasurable. If we only seek pleasure, then why in the world would anyone seek out unpleasant art? It must not be so unpleasant after all. Or at least this seems to be the line of thought. But once this implausible assumption is made explicit, we lack clear motivation for rejecting the second claim.

My formulation of the paradox makes explicit the underlying assumption of motivational hedonism. The first claim is simply a statement of motivational, or psychological, hedonism - the theory that the ultimate source of human motivation is pleasure and the avoidance of pain. This theory is certainly incorrect. Although psychological hedonists are a stubborn lot who more often than not are under the spell of some crackpot author of didactic fiction, I think it is fairly easy to show why their credo is false. In the proverbial foxhole, a soldier may throw himself on a grenade to save his comrades, thereby sacrificing his pleasure for the good of others. It takes some serious theoretical indoctrination to call this selfish! Only a philosopher could make such a claim with a straight face. Similarly, the morally motivated may pursue what they consider the right course of action instead of what would bring them the most pleasure. Further, one may occasionally promote the happiness of friends or loved ones at the expense of one's own pleasure. This is widely accepted endoxa. The burden of proof thus lies with the psychological hedonist.

Naturally the psychological hedonist has a reply: the reason one helps a friend or keeps a promise is because it brings one pleasure and allows one to avoid the displeasure of sympathetic suffering and guilt. The psychological hedonist has a point. It feels good to do good for others; guilt and sympathetic suffering feel bad. But the psychological hedonist fails to see the significance of the source of our pleasure and distress in the weal and woe of others. We enjoy doing good for friends because we care about them. Likewise, we feel bad when they suffer because we care about them. We wouldn't feel bad otherwise. And there is no reason to think that we care for our friends merely because it brings us pleasure to help them. Such a suggestion gets things backwards. The problem for psychological hedonism is this: if we can care about others, then surely we can be motivated by our care and not merely a selfish calculus concerning our expected hedonic payoff. ${ }^{10}$

Further, not all anhedonic motivations are benevolent. As the existentialists take pains to note, one may sacrifice one's own happiness for the pursuit of a meaningful project, knowing that it will likely bring more frustration and less pleasure than going to the beach. Although pleasure undeniably plays a significant role, it is most reasonable to think that pleasure is just one among many of sources of motivation.

Since motivational hedonism is false, the paradox of painful art quickly dissolves. A more plausible motivational theory, predominant motivational hedonism - the theory that people are predominantly motivated by the prospect of pleasure - does not create a paradox. But it does raise a pressing question: Why is it that people want to experience putatively painful art if it is indeed painful?

\subsection{A non-compensatory proposal}

As I've presented it, the paradox of painful art is essentially a conflict between audience reports and a default assumption of motivational hedonism. Given the plausibility of predominant motivational hedonism, the burden is likely on the proponent of the second claim. If audiences really do find some works of art painful, why do they want to see them? As I noted earlier, most theorists propose hedonic compensatory solutions to the problem, suggesting that audiences must find some pleasure to compensate for the pain. The principal problem with hedonic solutions is that they fail to accord with the phenomenology. Although there are surely many pleasures to be had from a well-crafted narrative, audiences do not always describe their experiences as on the whole pleasurable. In fact there are many cases where people describe their experiences as predominantly and genuinely painful.

Since the significance of this chapter rides on this point, it warrants additional support. Consider my favourite example: Ingmar Bergman's horribly depressing six-hour series, Scenes from a Marriage (1973). The 
third episode, 'Paula', is one of the most excruciating stories ever filmed. Marianne (Liv Ullmann) is at the summer house for the week with the children. Her husband Johan is not expected back until the weekend. When he makes a surprise midweek visit, Marianne is overjoyed. She runs around the house merrily fixing Johan a snack, saying how happy she is that he arrived earlier than expected. Her happiness makes Johan's news all that more crushing: he tells Marianne that he has fallen in love with another woman (Paula) and will be leaving that night with his mistress on a six-month trip. Their conversation lasts for an excruciating half hour of screen time, during which Johan proceeds to show Marianne, albeit at her request, a wallet picture of his lover! Throughout the course of the scene, Bergman uses a series of tight close-ups on Marianne's face as she experiences waves of hurt, indignation, frustration, and rage.

I would not describe my experience of this episode as pleasurable, but I find it to be one of the most effective 'unfaithfulness' fictions ever created. In film heaven it sits next to Murnau's masterpiece, Sunrise (1927). Indeed, it contains some of the most powerful moments in cinematic history. I would strongly recommend it to others, largely for the experience it affords. But it is not pleasurable. No, it is nothing less than emotionally devastating. At several moments along the way, if you stopped the film and asked me what I think, through a mist of tears would say it is terrific and absolutely crushing. This is precisely what makes it a masterpiece.

One might reply that although pleasure might not be the source of motivation, audiences must be seeking out some other source of value The painful experiences are perhaps instrumental to this value, but the pain is not intrinsically valuable. The problem with this objection is that it does not accord with the way we talk about painful art. Audiences do not talk about even the most painful experiences had in response to art as having mere instrumental value. Watching Scenes from a Marriage is not like going to the dentist. In subjecting ourselves to Bergman's film we do not, so to speak, endure the drilling in order to end a throbbing ache. Certainly we may find value in the film's insightful portrayal of suffering and marriage, but that does not exhaust our motivation. Although audiences may find various forms of value in experiencing the work, no compensation is necessary for the negative experiences it engenders.

Although the painful emotional responses one feels in response to art are not instrumentally valuable, one might suggest that they are constitutive of other types of value, such as the cognitive value of recognizing humanity's profoundly depressing proclivity to cruelty. Somehow, as I will argue below, fully understanding such insights necessarily involves painful emotional experiences. This style of explanation is highly plausible. Indeed, I think it is part of the complete motivational story. I will thus return to this suggestion, but what it would have to show, if it were to provide a reason to reject my initial claim, is that audiences only desire painful emotional responses as constitutive of other kinds of value, and never for themselves. I find this highly implausible, especially since the kinds of cognitive value one can take from art are typically banal. We know all too well that the universe is indifferent to our desires and that people are capable of beastly acts of violence, cruelty, and gross insensitivity. It is hard to imagine that the desire to be reminded of such depressing trivialities is the primary source of audience motivation, one to which our willingness to undergo all negative affect must be attributed. Surely it accounts for some of our motivation, but it seems that audiences do in fact desire the ultimately unpleasant experiences for the sake of having the experiences. At least that is how we often talk about such works: we applaud Bergman's powers of emotional devastation in addition to his humanity and depth of insight.

So it seems that audiences do indeed seek out painful works of art at least in part for the painful experiences they afford. Narratives provide long and varied experiences. Most provide at least some pleasures. But overall, some works are best described as painful. I argue that although we seek out painful art for a variety of reasons, one reason is for the experiences themselves. When engaging with painful art one sometimes intrinsically desires the nonpleasant experiences they afford. Perhaps this sounds odd, but there is good evidence for my claim: after the fact, we praise many works for their effectiveness at eliciting just such painful responses. We praise Scenes from a Marriage for its power to disturb to elicit heart-wrenching, painfully felt sorrow. In part, this is what we intrinsically desire from the work.

Elsewhere, I dub this the rich experience theory (RET). ${ }^{11}$ The theory holds that audiences desire painful works in part for the rich experiences they afford, experiences they cannot have in their daily lives, at least not without risk of serious bodily harm or worse. A common objection to RET comes from works that are wildly repugnant. Although I am a horror film fan, I can't stomach 'torture-porn', such as Saw (Wan 2004), Hostel (Roth 2005), or The Human Centipede (Six 2009). Nor do I like films involving graphic operations of eye surgery. I'm not alone here. At a screening of Passio (Paolo Cherchi Usai 2006) in New York, the audience fled in droves during a extended scene that one-ups Bunuel in Un Chien Andalou, featuring the surgical slicing of a human eyeball, lids 
pried open à la Alex in A Clockwork Orange (Kubrick 1971). ${ }^{12}$ Here's the objection: if audiences find unpleasant experiences intrinsically desirable, then why do so many people, myself included, avoid these kinds of experiences? RET predicts that audiences would behave other than they actually do. Accordingly, we should reject RET. Audiences must want something else, something besides the painful experience.

Although I think that this objection gets at something very important, it does not provide a reason to reject the basic claim of the rich-experience theory. Note that I didn't call my theory the 'intense experience theory'. It is not mere intensity that we find valuable, but experiences that are cognitively, sensorily, and affectively engaging: that is, rich experiences. An overwhelmingly disgusting experience is not rich. It's intensely disgusting, but lacking in other dimensions. Fully specified, the rich-experience theory avoids the problem of repugnant art. Nevertheless, the objection does point the way to a significant limitation of RET.

I never claimed that the rich experience theory tells the entire story about audience motivation, but I now suspect that it has less explanatory power than I previously thought. Audiences may indeed desire unpleasant and downright painful experiences for their own sake, but there is much more to be had from painful art. As noted above, I think that compensatory suggestions strike a false note. They don't accord with how we typically praise distressing works. We rarely say that watching a distressing movie was worth it, say, for its cognitive value - worth it in spite of the pain. No, we make more synoptic evaluations. Hume was aware of this. On a plausible interpretation, Hume argues that the pain experienced in response to tragedy is converted into pleasure via the artistry of the narrative. ${ }^{13}$ His suggestion is often called the conversion theory. I think that he was on the right track, but rather than a hedonic conversion, what we find is that painful emotional reactions are integral to other kinds of value. ${ }^{14}$ They are not so much converted as they are constitutive of valuable ends. Just as a brushstroke may have little value outside of a painting, in context the brushstroke plays an essential part in a valuable whole. The brushstroke is not intrinsically valuable, nor is it merely instrumentally valuable. Rather, it is constitutively valuable.

This is all fairly abstract. But it can be made more concrete by reflecting on our engagement with sad songs. If we reflect on our experience with sad songs and discuss the phenomena with others, it quickly becomes clear that sad songs frequently make us feel worse. Not only do they make us feel worse, it seems that we desire them precisely because they heighten our suffering. Sometimes a sad song might help us grieve; it might help us to purge our sorrow by 'having a good cry' along with it. But more often than not, we do not purge our sorrow in listening to such songs; we instead enhance it. We seek not catharsis, in the sense of purgation, but the welling of emotion. ${ }^{15}$ Although this sounds odd, it has solid phenomenological support.

One may listen for formal elements and delight in the arrangement of a sad song, but one is typically also presented with poetry, sometimes a narrative that requires a different kind of listening. ${ }^{16}$ Most songs provide only skeletal narratives which along with vivid imagery provoke personal associations. These provide the catalyst for imaginative reflection. The end result is intensely felt emotions directed at thoughts of the personalized narrative content.

It is not uncommon for people to listen to sad songs as a way of intensifying negative emotions; we do this partly as a means of focusing our reflection on situations of great importance. Emotional reactions have a searchlight effect; they enhance our focus. Just as fear rivets our attention to a dangerous object, strong emotions can help us achieve profound levels of concentration, thereby affording rich reflective or imaginative experiences. Sad songs, particularly those with suggestive narrative structures, aid in self-reflection. They have this instrumental value. Backed by mood-inducing instrumentation and vocalization, the narrative content of sad songs seeds our reflection on personal events. This is not always therapeutic. Dwelling on a loss, a misstep, an unfortunate circumstance does not always lead to acceptance or atonement. It can lead to frustration and suffering. But profound loss deserves profound grief.

The value of these experiences is not immediately clear. But it seems plausible that sad songs can help us see what we have had as well as what we have lost. Reflection does not always make us feel better. Indeed, sometimes it makes things worse. But we also want to understand what we have lost and to feel the significance. The value of such emotionally charged reflection is not merely cognitive, but it does serve to deepen our understanding. We listen partly for the experiences themselves, but the experiences are also constitutive of our enhanced understanding. Partly what it is to appreciate the significance of some event is to feel it to feel the significance. We assume that those who feel nothing have yet to accept their loss. They certainly do not understand the significance, at least not yet.

This might sound a bit obscure, but we frequently make use of this notion of understanding. It is not knowing-that and it is not knowing-how, it is something different - a matter of understanding the felt 
significance of a situation. Imagine asking someone if they understood the enormity of some genocide, battle, bombing, or other horrific event. In reply they say, sure, and spin off a few statistics. We ask: 'Isn't it just awful to think about? It's incomprehensible.' A reply that, 'No, it is perfectly comprehensible: $\mathrm{x}$ number of people died', misses the point. As William James notes, in such a case the person has a mere 'cold and neutral state of intellectual perception'.$^{17}$

Similarly, consider someone who is completely unmoved at the death of a friend's child. It is incoherent to say: 'I understand how horrible it is to lose a child, but it just doesn't sadden me one bit'. Either they do not care, or they simply do not understand. This is not merely a matter of knowing how it feels to lose a child. It is a matter of understanding the significance of the loss. Of course, in extremes one may be overwhelmed, moved into a nearly affectless state, but before this extreme, one cannot even approximately understand the loss of a child without feeling pity or grief. The same goes for things that happen to us. Understanding the significance of things that matter to us sometimes requires feeling profound sadness. ${ }^{18}$ It is not that the emotion is merely indicative of our understanding; rather, it seems that having the emotion is part of the understanding itself.

This notion of understanding is admittedly somewhat obscure. Unfortunately, I am unsure how to make the idea much clearer. In less controversial terms, one might describe the kind of understanding at issue as a form of appreciation. Cheshire Calhoun argues that emotions help one gain an 'evidential' (as opposed to a merely 'intellectual') grasp on one's beliefs. ${ }^{19}$ One might know some fact or another, but not appreciate it. Coming to appreciate a descriptive fact is a process of understanding its implications and becoming ready to deploy it in future thought. We should expect something similar to be the case with evaluative facts. Most plausibly, painful emotional responses can be instrumental to evaluative appreciation. But I am not entirely happy describing the kind of understanding at issue as a mode of appreciation.

If appreciation were the full extent of the value of the painful emotional responses, then I would be merely offering a nonhedonic compensatory theory. There's nothing wrong with that. Except that I think something stronger can be said, namely, that emotional reactions are sometimes constitutive of evaluative understanding. I will focus on the clearest example I know, one where one's emotions are integral to a kind of selfknowledge about one's evaluative commitments, about what one values.

On most accounts, we need not care about all that we believe is valuable. But to value something is surely more than merely believing it valuable. It appears that to value something is to believe that it is valuable and to care about it. Both are necessary. For instance, one might believe that the life of a starving child halfway across the globe has value, but if the child's fate leaves one cold, it does not seem appropriate to say that one values the child's life. ${ }^{20}$ If one does not care, one does not value. ${ }^{21}$

Unfortunately, the nature of care is almost as murky as the notion of understanding that I am trying to explicate. But at least one thing is clear: care cannot be defined apart from its relation to the emotions. One might go so far as to think of care as a mere disposition to emotion. I think that this is a mistake. Since caring gives rise to a variety of different emotions, actions, and thoughts, it cannot be reduced to a mere disposition to emote. All I am confident in affirming is that our emotions depend on what we care about. ${ }^{22}$ For example, we only fear for that which we care about. In general, standard emotions essentially involve evaluations of the way something we care about stands to be or has been affected. ${ }^{23}$ But it is incoherent to think that someone could care about something and not be prone to feel fear when it is threatened, or hope when it stands to flourish. Accordingly, it is uncontroversial to suggest that our cares are sometimes revealed to us by our emotional responses.

Ultimately, we need to feel in order to understand what we care about and how much we care. Sad songs, in particular, afford us the opportunity to feel and thereby understand what we care about. The painful emotional responses they encourage are constitutive of our understanding the personal importance of a loss, of how important something is to us. ${ }^{24}$ This is a significant source of their value.

\subsection{Welfare, an overview}

In the Introduction, I briefly presented a troublesome implication of the constitutive solution to the paradox of tragedy: it implies that painful art is bad for us. I noted that this implication results only if we assume a controversially narrow theory of well-being. I turn now to explain the problem in more detail. To fully appreciate this problematic implication, we must first get a little clearer about the nature of well-being.

Theories of welfare (a.k.a., well-being, self-interest, and prudential value) tell us what makes a life good for the one who lives it. Things that are good or bad for a person affect her well-being - her good, her welfare. They have prudential value. Accordingly, theories of prudential value tell us what is in a person's self-interest. The notion of welfare is central to a variety of concepts, such as harm and benefit, self-sacrifice, and selfishness. 
There are three general contenders in the welfare literature: mental statism, desire-satisfactionism, and objective list theories. ${ }^{25}$ The standard presentation of the dialectic begins with a narrow theory and proceeds in response to objections that favour broader theories. ${ }^{26}$ Mental statism is the narrowest theory. It holds that the sole bearers of intrinsic prudential value are mental states. ${ }^{27}$ Hedonism, for instance, is a type of mental statism. It holds that only the mental states of pleasure and pain are intrinsically prudentially valuable. ${ }^{28}$ In its simplest form, the value of a life for the one who lives it is equal to the net balance of pleasure over pain. ${ }^{29}$ Hedonism is the most popular form of mental statism. If experiences are all that count, what could be more fundamental than pleasure and pain?

Although hedonism is the most popular variant of mental statism one need not be a hedonist to be a mental statist. I find mental statism compelling, but I think that hedonism is implausible. It is implausible because many nonpleasurable experiences appear to be intrinsically prudentially valuable. At least, many pleasurable experiences appear to be prudentially valuable disproportionate to the pleasure involved. I suspect that this is partly what Mill tried to capture with his theory of 'qualitative hedonism'. Think of embracing a loved one. It might be pleasurable, but the prudential value of the experience exceeds its hedonic quotient. Or consider flow experiences: it is not clear that they are very pleasurable, but surely they are prudentially valuable mental states. ${ }^{30}$

Most controversially, mental statism implies what is known as the experience requirement - the claim that what you do not experience cannot hurt you or cannot constitute a harm for you. ${ }^{31}$ There is a decent consensus, although not without dissenting opinion, that experience machine-style examples show that the experience requirement and by implication, mental statism are false. ${ }^{32}$ Nozick asks us to imagine a machine that can simulate a wide array of fantastic experiences. ${ }^{33} \mathrm{He}$ gives us what is by now a familiar sales pitch: Perhaps you want to write the great American novel. In the experience machine you can have the experience of writing the most celebrated novel in history. Your work will be praised far and wide. Champion athlete, war hero, legendary lover, you name it - in the machine, you will experience any life that you desire. Most important, life in the machine will seem as real as any experience that you have ever had. You will never know the difference.

Nozick asks us whether given the chance we would step into the machine. Intuitions diverge, but many, if not most, people decline. Most of us opt out of the machine because we do not merely want to think that we have written the great American novel; we want to actually have written it. We do not merely want to think that we have genuine relationships; we want to form genuine bonds with others. We like to win, but we do not want every game to be fixed in our favour.

Opponents of hedonism take our reluctance to live a life in the machine as evidence that we want more than mere happiness in the ordinary sense. Defenders of desire satisfactionism concur. They hold that a life in the experience machine is deficient because it fails to satisfy a wide variety of our desires, such as the desire for contact with reality. Hence, they conclude that it is not merely pleasure that makes a life good for the one who lives it, but the satisfaction of our desires. ${ }^{34}$

The next move in the debate widens the scope even further. Imagine a woman who could make significant contributions to applied mathematics, but instead prefers to spend each day counting the blades of grass on Harvard Yard. ${ }^{35}$ Her desires are satisfied, but she does not live a good life. Clearly, the objection holds, she would be better off doing something objectively worthwhile. To account for the grass counter, some propose an objective list theory (OLT) of well-being. ${ }^{36}$ This theory holds that the more objective goods and fewer objective bads in a life, the better the life for the one who lives it. The objective goods are commonly thought to include such things as loving relationships, knowledge, the appreciation of genuine beauty, virtue, autonomy, and achievement. ${ }^{37}$

\subsection{The painful art problem for mental statism}

The above discussion suggests that mental statism is a fairly unattractive theory. The problem of painful art appears to give us yet another reason to reject the view. As I noted in the Introduction, if we accept hedonism, then nonhedonic compensatory and constitutive solutions to the paradox of tragedy imply that it is bad for us to watch melodramas and to listen to love songs, assuming they don't bring us a surplus of pleasure further down the road. If the pain is not compensated hedonically, we come out, on balance, worse off. We would be better off staying away from such works. Accordingly, depending on one's theory of rationality, it would be irrational to watch them or listen to them. But this is absurd. If something along the lines of the constitutive solution is right, the worry is that hedonism - and most likely, mental statism - about wellbeing must be wrong.

I disagree. In the remainder of this section I will provide a brief defence of mental statism and set the stage for the resolution to the problem. Rather than an objection to mental statism, I think we should regard 
the foregoing as reason to think that welfare is not all-important. We can admit that on many occasions painful art may indeed be somewhat bad for people, but we need not think that this gives us good reason to stop attending melodramas or listening to sad songs. Audiences seek out nonprudential forms of value, such as self-knowledge, from most painful art, and they are perfectly rational to do so.

Consider once again the experience machine: although most nonfrivolous, nonterminally ill people would opt out of a life in the experience machine, this does not constitute a decisive objection to mental statism. Yes, the thought experiment clearly shows that we want more than mere experiences, but it does not show that things without experiential impact can affect our well-being. The thought experiment merely confirms what we already know: we desire many things other than our own well-being. ${ }^{38}$ Strict psychological egoism is highly implausible. We often nonselfishly desire the good of others. People frequently sacrifice themselves for a cause or for the benefit of those they love. And many people have been known to sacrifice their own well-being for other kinds of goods, such as knowledge, contact with reality, moral worth, and meaningfulness.

Most of us think that a life in the experience machine would be meaningless. Insofar as we desire meaningfulness, we will opt out of the machine. ${ }^{39}$ This does not show that we think that we would be better off - that we would have a higher state of welfare - outside of the machine. Life in the machine simply cannot give us everything we want. Since we want more than what merely increases our well-being, the case against mental statism is inconclusive.

Perhaps mental statism is unscathed by the experience machine, but one might nevertheless think it implausible. Indeed, one might suggest that the value had from painful art lends support to objective list theories of welfare. For instance, one might claim that we are benefited by the understanding we acquire through the painful emotions aroused by sad songs. Since other varieties of painful art help us appreciate evaluative facts, they too are good for us. They make our lives intrinsically better by enhancing our self-knowledge.

I do not think that we should make this move. Although I agree that the objective-list theory of well-being has intuitive pull, it suffers from some serious difficulties. I will briefly consider three. First, the most pressing problem comes from the person who takes no pleasure from the objective goods. Consider the reluctant cancer researcher: although he has an aptitude for biochemistry, he derived little enjoyment from his studies in college. He only pursued the field out of pressure from his father. Despite his dissatisfaction, he made several major discoveries that revolutionized cancer treatment. Although his life was high in achievement value and knowledge, it was not a good life for him. He was chronically dissatisfied. Despite the objective goods, the cancer researcher did not have a life high in individual welfare. Take any, and perhaps all, of the goods on the objective list and we can concoct a similar scenario. This suggests that it is not objective goods, but some subjective state, such as happiness, that is most important for welfare.

To save the theory, it will not suffice to merely include pleasure or happiness in the list of objective goods. The reluctant cancer researcher would be deficient in this regard, but high in several other such goods. Yet his life would still be low in prudential value. ${ }^{40}$ Hence, happiness appears to be of far greater prudential importance. It is hard to imagine a non-ad hoc explanation for why. A more promising move available to defenders of the OLT of welfare is to construct a hybrid version of the theory: the objective goods must be subjectively appreciated, either by taking pleasure in or by desiring the objective good. But the hybrid theory suffers from a second problem.

Consider a life with a good amount of subjective appreciation. Now imagine a variation: keep the subjective appreciation, happiness, and satisfaction the same and increase one of the other goods, such as the significance or generality of the knowledge. The problem is that it is hard to see how this change improves the value of the life for the one who lives it. ${ }^{41}$ If something is good for someone, it seems that it needs to affect the intrinsic properties of the person. It must be a 'real change' in the person. This is clearly the case for nonhuman welfare subjects. If you do not affect the intrinsic properties of a cat, you do not do anything good or bad for the cat. Although it is not clear that plants have welfare, it is clear that nothing is good or bad for tomato plants unless it affects their intrinsic properties. This is likely not a sufficient condition, as not everything that affects one's intrinsic properties affects one's well-being. But it is plausibly necessary. How could something that does not change me make my life better for me?

I know of no decisive argument for this claim. ${ }^{42}$ Nevertheless, it seems secure. The problem is that the intuitive plausibility of this condition is at odds with the implications of the OLT of welfare. This does not show that the OLT of welfare is false or contradictory. Rather, it shows that the OLT has strong counterintuitive implications. In fact, the OLT of welfare denies a claim that is likely more secure than any considerations in favour of the theory held individually or jointly. 
Third, the objective-list theory of well-being makes it nontrivial to account for self-sacrifice, far more difficult than is plausible. ${ }^{43}$ This is particularly clear if the theory includes moral worth as one of the objective goods. In response to a case of heroic self-sacrifice, the OLT of welfare might be able to account for the welfare impact of the sacrifice in an overall evaluation, where the losses outweigh the gains from supererogation. But the general strategy sounds very odd. I do not think that OLT of welfare makes supererogation selfish. I am not confusing the motivation with the result of the action. The OLT theorist can coherently acknowledge that the self-sacrificing hero need not be motivated by self-interest. The problem is that it is very odd to say of someone who rushed into a burning building that it was a great loss for him apart from the prudential benefits of the self-sacrifice. It is not just that the tally sheet comes out in the prudential red, but that the self-sacrifice doesn't have any prudential benefit. The only goods for which one cannot coherently sacrifice one's welfare, at least not directly, are valuable experiences. Only mental statism avoids the problem of self-sacrifice.

These considerations strongly count against an OLT about welfare. But the value had from painful art does lend support to a closely related theory, an objective-list theory of worth. In the next section I explain how making a distinction between well-being and worth helps solve the problem set out in the introduction.

\subsection{The limits of well-being}

In the previous section, I argued that the OLT about welfare faces a significant problem accounting for self-sacrifice. This problem is pronounced if one includes the moral worth of our actions on the list of objective goods. But it is implausible that moral worth is a prudentially relevant good. This has significant implications for thinking about welfare.

Brad Hooker argues that we do not pity the wicked. ${ }^{44}$ Since appropriateness of pity is a good test of the loss of welfare, we have good reason to think that the moral worth of our actions does not directly impact our welfare. There are reasons to doubt the soundness of Hooker's argument, but not the truth of the conclusion. We typically only pity underserved suffering. But if wrongdoing harmed the wrongdoer, the negative welfare impact would be deserved. Hence, it would not be cause for pity. Contra Hooker, it is not the absence of pity that shows the intrinsic irrelevance of moral worth to welfare, but the appropriateness of indignation. Others have noted that the reason it is bad for the vicious to experience pleasure is that the prudential good is underserved..$^{45}$ The thing that makes malicious pleasure so awful is that it benefits the vicious person. If we thought that wrongdoing was bad for the wrongdoer, we could not account for the particular offensiveness of the prosperous gangster. The source of our indignation gives us good reason to think that moral worth does not impact our welfare.

Although immorality does not clearly make one intrinsically, prudentially worse off, the moral value of our actions is nevertheless important to the evaluation of our lives. Most intuitively, a life that significantly advances horrendous evil is not worth living. Hitler, Pol Pot, and Stalin lived lives of negative worth. Killing millions of people is hideously evil. And, most plausibly, moral repugnance is sufficient to sap a life of positive worth. But it is not the only thing to do so. Intense pain can suffice. Lives spent in persistent, incapacitating agony are not worth living. By any plausible account, they are lives worth avoiding (LWA). They are objectively worth avoiding.

There are clear cases of lives not worth living. And there are not so clear cases. Worth comes in degrees. Lives entirely consumed by meaningless activities, such as counting blades of grass, collecting rubber bands, or making handwritten copies of War and Peace, appear to be less worth living than those spent in pursuit of valuable ends, but it is not so clear that they are not worth living. ${ }^{46}$

A theory of worth will answer this question: What makes a life worth living (LWL)? This is not the same question as what makes a life good for the one who lives it. ${ }^{47}$ As we have seen, a theory that answers the latter question is a theory of well-being. The two questions are clearly related, and they are often conflated. ${ }^{48}$ But most likely worth is not strictly a matter of welfare, since one can live a life of great hardship and suffering that might nevertheless be worth living. ${ }^{49}$ Prima facie compelling examples abound: again, the proverbial soldier who throws himself on a grenade to save his comrades does not enhance his welfare. But he does improve the worth of his life. ${ }^{50}$

Achilles's choice, recounted in the Iliad, illustrates the point. Achilles knew that if he entered the battle against the Trojans, he would die soon, but that his name would live on for ages; alternatively, if he stayed out of the fight, his name would be forgotten, but his life would be long and happy. He chose a short, meaningful life over a long life high in individual welfare. He was not merely motivated by a desire for fame, but for achievement and, more significantly, revenge for Hector's slaying of Patroclus. By entering the battle, Achilles did not enhance his welfare. But, plausibly, he did improve the worth of his life. 
Just as some things that do not promote our self-interest are nevertheless worth doing, some lives low in welfare appear to be worth living. When we wonder whether some activity is worth doing, 'What's in it for me?' is typically not our only thought. Intuitively, the same should hold for lives. Conversely, some lives high in welfare are not worth living. Most plausibly, a supremely happy Hitler does not live a life worth living. It would be highly counterintuitive to suggest otherwise. More needs to be said, but these considerations suggest that worth and welfare are distinct. Not only are they conceptually distinct, they are extensionally nonequivalent.

Regardless of whether the experience machine-objection refutes mental statism about welfare, it has important implications for the theory of value. Although some think that you could live a prudentially highly valuable life inside the experience machine, few think that you could live a very meaningful life inside the machine. This shows that there is a conceptual difference between meaning and well-being. If they were conceptually identical, it is hard to see how we could be less certain about how meaningful a life could be in the experience machine than about how high in welfare such a life could be. But many people are indeed far less certain about one than the other. Perhaps the set of lives high in meaning will be identical to the set of lives high in welfare. I doubt it, but either way there is a conceptual difference.

The distinction between welfare and meaning is compelling, as is the distinction between welfare and worth. But one might wonder if worth and meaning are two different kinds of value. I think they are. ${ }^{51}$ Even without developing a theory of the meaning of life, we can see that there are good reasons to think that worth and meaning are distinct concepts. A largely meaningless life might nevertheless be worth living. Consider a happy rubber-band collector: it is not clear that the rubber-band collector's life is entirely not worth living; however, apart from whatever limited achievement value results from having a large horde of rubber bands, his life is decidedly meaningless. His life is meaningless, but not entirely worthless. Hence, worth is not entirely a matter of meaning. But meaning is nonetheless relevant to worth. Other things being equal, the more meaningful a life, the more it is worth living. Once again, consider the life of the brave soldier, Mother Teresa, or Abraham Lincoln. These considerations give us reason to think that worth is a higher-level mode of value, one that encompasses lower-level values such as meaning and well-being. ${ }^{52}$

Although I cannot here develop a full theory of worth, the discussion so far lends itself to an objective-list theory. Most plausibly, lives worth living are those high in various objective goods and comparatively low in objective bads. On a tally sheet for a life worth living (LWL), the goods come out far ahead. A life worth avoiding (LWA) is the opposite: it is high in bads and low in goods. ${ }^{53}$ I claim no originality in the list of goods, and I will not try to offer an exhaustive list, but for simplicity's sake we can think of them as involving two main categories, those of welfare and meaning. More precisely spelled out, we would expect the list to include most of the following: happiness, moral worth, loving relationships, knowledge, the appreciation of genuine beauty, virtue, autonomy, and achievement. The principal virtue of the OLT of worth is that it helps capture the importance of a wide swath of concerns that do not clearly impact one's welfare. For instance, it seems that I can selfsacrificially pursue ends that do not make me better off prudentially, but that nevertheless enhance the worth of my life. Similarly, enhancing my evaluative understanding via painful art might enhance the worth of my life without affording much, if any, prudential benefit.

The distinction between well-being and worth thus provides the key to solving the problem I introduced in the introduction. Rather than focus on the welfare impact of painful art, we should be concerned with its impact on the worth of our lives. Most plausibly, the value had from painful art often makes our lives more worth living, despite sometimes having an adverse affect on our welfare. And it is not irrational to pursue works of art that make our lives more worth living.

\subsection{Conclusion}

In this chapter I explored the implications of a nonhedonic solution to the paradox of tragedy, or what I call 'the paradox of painful art'. It certainly seems that people are far more willing to experience negative emotions in response to art than in their daily lives. This difference begs for an explanation. Why do people desire to see melodramas or listen to sad songs? More specifically, we might ask, why do people seemingly want to be scared by a movie or feel pity for a character when they avoid situations in real life that arouse the same emotions?

The most popular solution to the problem is a hedonic-compensatory theory. It holds that audiences find other sources of pleasure to compensate for the pain. I argue that the hedonic-compensatory theory lacks phenomenological support. Not only does the hedonic-compensatory theory fail, it appears that painful art frequently fails to provide sufficient prudential compensation, at least on a mental statist conception of welfare. Rather than see this as a reductio of mental statism, I think 
we should accept the implication. We do not always seek out painful art to improve our welfare. There are other forms of value to be had, such as an improved understanding of our evaluative commitments. I argue that even though painful art may not always enhance our well-being or contribute to welfare, it can very well enhance the worth of our lives. ${ }^{54}$

\section{Notes}

1. There are a variety of solutions in the literature. Control theorists argue that the putative painfulness of some works of art is mitigated by our ability to stop experiencing them at will (Morreall 1985). Compensation theorists argue that any painful reactions must be compensated for by other pleasures, either in the craft of the narrative (Hume 1985) or in the awareness that we are sympathetic creatures responsive to the suffering of others (Feagin 1983). Conversion theorists argue that the overall experience of painful works of art is not one of pain but of pleasure, as the pain is converted into a larger, more pleasurable experience (Hume 1985). Power theorists argue that we enjoy the feeling of power that arises from either the realization of the endurance of humanity (Price 1998), or through the overcoming of our fear (Shaw 2007) Rich experience theorists argue that there are many reasons why people do things other than to feel pleasure. The overall experience of painful art may be one of pain, but the experience can still be seen as valuable, and, as such, motivating (Smuts 2007). Levinson (1997) and Smuts (2009) survey the literature.

2. Chisholm (1973: 21)

3. A small subset of the literature, its oldest part, is principally concerned with moral issues. Plato worries that tragedy threatens the moral character of audiences. He argues that enjoying suffering renders audiences less capable of enduring hardship without excessive, 'unmanly' grief (Republic X.605d-606b). In general, he fears that tragedy makes audiences limp-wristed, licentious (Republic X.606d) buffoons (Republic X.606c). In contrast, Augustine (2008: 36; III.ii) worries more generally that it is problematic to take pleasure in the theatre. He implies that it is somehow selfish to derive pleasure from our viewing experiences. More recently, some wonder if it is ethically suspect to take pleasure in the suffering of fictional characters. Hurka (2001: chapter 6) and Smuts (circulating) provide comprehensive discussions of the issue. Due to limitations of scope, I must put the moral issues aside.

4. Neill (1996: 181-182) argues that the film requires empathetic engagement to be successful.

5. 'Nostalgia' comes from the Greek algos ('pain' or 'distress') and nostos ('to return home')

6. Broad (1959) develops a sophisticated version of the hedonic tone theory of pleasure. But hedonic tone theories of pleasure have gone out of fashion. The 'heterogeneity problem' is thought to provide a decisive refutation of this general family of theories. See Alston (1968) and Feldman (2006) for a presentation of the problem. Smuts (2010) defends a hedonic tone theory.
7. There is some debate as to whether non-sensation-based pain should be thought of as literally or only metaphorically painful. One might propose that psychological pain be called suffering. The analog for pleasure would be to call psychological pleasure joy. Sumner (1996: 109) makes this distinction. I agree that 'suffering' and 'joy' are apt descriptions of general evaluative attitudes, but I cannot find a clear line between psychological and sensory pain and pleasure. Psychological pains typically feel bad, just like cuts and scrapes. And psychological pleasures often feel good, as does a sweet snack. This should be clear as long as one does not call all states where one is 'pleased that' such and such is the case pleasure. Clearly, most are not. I can be pleased that lots of things are the case without feeling any pleasure.

8. See, for instance, Levinson (1982).

9. Elsewhere I consider two other explanations for why the second premise is commonly targeted (Smuts 2007).

10. See Bishop Bulter (Sermon XI) for a similar line of argument

11. Smuts (2007).

12. Much of the Austin audience seemed to enjoy a screening of the gruesome flick Sick: The Life \& Death of Bob Flanagan, Supermasochist (Dick 1997) that I attended in the late 1990's. This film was a roller-coaster of discomfort. I still cringe when thinking about Flanagan nailing his penis to a board. Apparently watching masochism is very different from watching torture.

13. Hume (1985).

14. Some such explanations would be appropriately classified as what Levinson (1997: 30) calls 'organicist' explanations, where the negative affect is thought to be a necessary part of a valuable organic whole.

15. I like to call it 'anti-catharsis.' But this courts controversy. I do not think that the notion of anti-catharsis tracks the purification interpretation of Aristotle. But this might be because I can't make much sense of the purification model. In any case, I prefer not to teach old words to do new tricks, so here I follow the popular conception of catharsis as purgation, or flushing out.

16. Smuts (2011) provides a more in depth discussion of listening to songs. Here, I draw on and elaborate my previous defence of the value of sad songs.

17. James (2003: 70).

18. Blum (1980: 173-178), Nussbaum (1994: chapter 10; 2001, chapter 1, IV; and 2003), Oakley (1992: 50-51), Stocker (1996: 183-184), Taylor (1985: 61-62), and to some extent Williams (1973: 225-257) make similar suggestions. Starkey (2008) provides a rare sustained discussion of the issue. He defends the claim that the emotions are required in order to achieve certain kinds of understanding. Similarly, Oakley argues that 'having certain emotions may sometimes be necessary for understanding some features of the work, such that an appreciation of these features would be beyond an unemotional person' (50). It is unclear if he adopts an instrumental model as does Starkey. Rather than a constitutive solution, Starkey's model supports a compensatory solution.

19. Calhoun (2003: 242-244).

20. I have at least one reservation about this story: It is unclear what an affectless evaluative belief amounts to. I am not sympathetic to non-cognitivism, but I nevertheless find it suspect to suggest that someone can fully understand the value of something without caring about it. At least their knowledge would 
appear deficient. But then again, I suppose that one need not care much about the victims of an ancient atrocity to understand the horror.

21. It is less clear that one can care about something without believing it valuable. Shoemaker (2003: 96-97) discusses the relation between valuing and caring.

22. Roberts (1988) forcefully defends a similar view. Helm (2009) defends a related claim about concern. Shoemaker (2003: 91-93) argues that we can only make sense of our emotions in light of our cares. But all three appear to accept a dispositional account of care. Jaworska (2007) thinks of care as something of a complex emotion.

23. As many have noted, emotions seem to require that one care about that which was or stands to be affected by the object of the emotion. For instance: Taylor (1985: 400-401) notes the connection, as does Stocker (1996: 175). Solomon (1980: 276) argues that emotions are personal and involved evaluations. Taylor (1985: 59-62) argues that emotions reveal what we value, what matters to us. They are import-ascriptions. Roberts (1988: 188-189) claims that emotions are grounded in concerns. Shoemaker (2003: 91-93) argues that emotions are conceptually connected to cares. Helm (2009: 5-6) notes that emotions have a focus, a locus of concern. Strangely, in his comprehensive and influential taxonomy of the objects of emotions, De Sousa (1999: chapter 5) leaves out the object of our concern. He uses 'focus' differently, to refer to the focus of attention: for example, the snarling dog's menacing teeth.

24. Following Chrysippus, Nussbaum (1994: 45) makes a much stronger claim: 'the real, the full recognition of that terrible event (as many times as I recognize it) is the upheaval.' In a later work she argues that the belief is identical with the passion (Nussbaum 2001: 373-386).

25. Parfit (1984: 493-494) divides the terrain in this way. His taxonomy has been highly influential. Kagan (1992) defends an alternative.

26. For instance, see Kagan (1992), Parfit (1984), and Scanlon (1993: 186-191).

27. Kagan (1994 and 1992) confesses his temptation toward mental statism. He later (2009: 771, n. 3) recants.

28. Parfit (1984: 493) and Wolf (1997) reverse this distinction. They seem to hold that all forms of mental statism are forms of hedonism.

29. See Feldman (2006: passim) for more sophisticated forms of the theory.

30. The viability of non-hedonic forms of mental statism opens the way for a suggestion I cannot explore here. Rather than an objection to mental statism in general, painful art might give us reason to reject hedonism in particular. Perhaps painful art affords non-pleasurable experiences that are nevertheless prudentially valuable. Hedonism cannot account for this. But non-hedonic forms of mental statism can.

31. Griffin (1986: 13). For further discussion see Sumner (1996: 127-130). Since the experience requirement is not always presented in the same way, I have chosen to focus on mental statism. Soll (1998), for instance, defends a theory called 'experientialism' that has both motivational and broad axiological implications. Mental statism, as I have formulated it, implies only a limited axiological claim about well-being: Something can affect someone's wellbeing only if it makes an experiential difference for that person. This is not the same as what Dorsey (2011: 172) might call the endorsement requirement.
32. Nozick's (1974: 42-45) 'Experience Machine', Nagel's (1993: 64) 'Deceived Businessman', Nagel's (1993: 66) 'Contented Infant', Mill's (2002) 'Pig', and Nozick's (1997) 'Mongolian Pornographer' are the most pressing objections to mental statism.

33. Nozick (1974: 42-45).

34. Typically, the position holds that it is not the feeling of satisfaction that counts, but satisfaction in the logician's sense - that is, what we desire to be the case actually being the case. Heathwood (2006) defends a subjective version.

35. Rawls (1971: 432). See Feldman (2006: chapter 3) for a host of other objections.

36. Some of the more influential defences of OLT of well-being (not worth) include: Brink (1989: 221-236), Hooker (1996), Nozick (1989), and Scanlon (1993).

37. I present this as a plausible list, but cannot defend the individual items here. As intrinsic goods, Ross (1930: 140) lists virtue, pleasure, the allocation of pleasure to the virtuous, and knowledge.

38. In defence of mental statism, Haslett (1990) appeals to this distinction, as do Goldsworthy (1992), Bradley (2009: 10), Kawall (1999), and Feldman (2012: 67-72). For additional discussion of this line of argument, see Tännsjö (1998 111-112) and Sumner (1996: 96-97).

39. A desire for meaning is not the only thing that can motivate repulsion at the experience machine. Other desires will suffice, such as the desire for contact with reality.

40. Trianosky (1988) defends an OLT with a necessary subjective condition. Parfit (1984) finds the hybrid theory most plausible. Kraut (2008) seems to defend a hybrid theory, though he confusingly uses the label 'happy' to refer to well-being. Kagan (2009: 255) suggests a hybrid theory.

41. Dorsey (2011: 186) presents a similar thought experiment that putatively supports the opposite conclusion. As we will see, the OLT theory of worth can account for these apparent conflicts of intuition.

42. Kagan (1992: 186) finds himself in the same spot, and later rejects this claim (2009: 271, n. 3).

43. Similarly, desire satisfaction theories of well-being seem to imply that selfsacrifice is impossible. See Overvold (1980) for a forceful presentation of the issue. Heathwood (2011) defends a solution. The problem is worse for OLT theories.

44. Hooker (1996)

45. Hurka (2001: 242)

46. Rawls (1971: 432) and Wolf (1997: 211).

47. Feldman (2012: 161, 167, and 168) suggests that we commonly use the phrase 'a life worth living' as roughly synonymous with a life high in individual welfare. But I disagree.

48. This is likely because the phrase 'a life worth living' is somewhat ambiguous. The ambiguity is between 'worth for' the agent and objective worth. I have in mind the latter, which will include the former.

49. Darwall (2002: 26 and 109 n. 5) suggests that a life having worth is an estimable life. This is plausible, but he thinks that the contrast is between welfare and perfectionist value. Hurka (2001: 7) defends a similar distinction. 
There is reason to doubt this suggestion. Since worth appears to encompass subjective happiness, a non-perfectionist value, the contrast does not apply I also worry that Dorsey's (2011) arguments against perfectionist theories of welfare apply to perfectionist theories of worth. I will not explore this issue further here.

50. One might think that the notion of a life worth living should be called 'the good life'. But I am hesitant to adopt this label. The phrase 'the good life does occasionally show up in the literature on well-being, but it is not usec consistently. Feldman uses the phrase to refer to a life that is good for the one who lives it, by which he intends a life high in individual welfare. Although there is little precedent, his usage is atypical. [Feldman (2006: 12, n. 5) notes that the traditional notion of the good life might be one that encompasses several different kinds of goodness. Nevertheless, he continues to use the term to refer to a life high in well-being.] More typically, Daniel Haybron and Susan Wolf refer to something bigger, something much closer to what I am after. Wolf (2010) understandably interchanges concepts such as 'the good life' $(12,52$, and 118$)$, a life that would seem a benefit $(21,23$, and 27$)$, the 'fully successful life' (32), the 'fully flourishing life' (12), and the life good for the one who lives it (32). Since she thinks that the notion is different from self-interest $(56,63$, and 116$)$ and happiness (109), it appears that we might have in mind a similar notion. Similarly, when Thomas Hurka uses the phrase 'the good life' he seems to have in mind a life worth living. Hurka (2011) uses phrases such as: a 'good life' $(8,35$, and 67$)$, a 'valuable life' $(120)$, a 'better life' (7), and a 'desirable life' $(2,3,28,148$, and 186). He defends an objective list account. The goods include, but are not limited to pleasure, knowledge, achievement, virtue, and loving relationships. Although a chorus of voices speaks in favour of substituting 'the good life' for 'a life worth living', given the potentially misleading connotations, I will avoid the label. Most important, 'The Good Life' sounds very demanding. A somewhat mediocre life might be worth living, but we would be hesitant to call it 'The Good Life'.

51. Only a few have drawn a distinction between what makes a life worth living and what makes a life meaningful. As far as I can tell, Baier (1988) provides the first sustained discussion of the distinction. Baier (1997: 67-69) also makes a few passing remarks on worth. Apart from this, only Trisel (2007: 62-65) provides a substantial defence of the distinction. Metz (2007: 213) makes a clear statement of the difference, though he provides little defence. Metz (2002: 788, n. 10) also briefly notes the distinction. Blumenfeld (2009: 8, n. 2) seconds Metz's proposal, but does not develop a theory of worth. Haack (2002) proposes that we abandon the concept of meaning for worth. She does not explain the conceptual difference. Wollheim (1984: 444-448) proposes a distinction between a life worth living and a worthwhile life. I decline to adopt this terminology, since there is better, more familiar conceptual machinery; his distinction closely tracks that between welfare and meaning. Camus (2004: 533) appears to distinguish between meaning and worth: 'people have pretended to believe that refusing to grant a meaning to life leads necessarily to declaring that it is not worth living. In truth, there is no necessary common measure between these two judgments.' But he says very little about worth.
52. Trisel (2007: 2 ) argues that worth is a broader notion than meaning, but the theory he offers looks very much like a narrow welfarist account of worth. Hence, it's not clear if he would distinguish between welfare and worth.

53. The calculation will likely have to account for the intensity as well as overall quantity. An extremely painful episode might make the entire life worth avoiding. Also, an extremely long life that is barely positive in goods might not be a LWL, it might be a LWA.

54. I thank Jerrold Levinson for helpful feedback on an earlier draft of this chapter.

\section{References}

Alston, William (1968). 'Pleasure', in P. Edwards (ed.), The Encyclopedia of Philosophy (New York: Collier-Macmillan).

Augustine (2008). Confessions. Trans. Henry Chadwick (Oxford: Oxford University Press).

Baier, Kurt (1988). 'Threats of Futility: Is Life Worth Living?' Free Inquiry 8: 47-52.

Baier, Kurt (1997). Problems of Life and Death (Amherst: Prometheus Books).

Blum, Lawrence (1980). Friendship, Altruism, and Morality (New York: Routledge). Blumenfeld, David (2009). 'Living Life Over Again', Philosophy and Phenomenological Research 79(2): 357-386.

Bradley, Ben (2009). Well-Being and Death (Oxford: Oxford University Press).

Brink, David (1989). Moral Realism and the Foundations of Ethics (New York: Cambridge University Press).

Brink, David (2008). 'The Significance of Desire', in Shafer-Landau (2008).

Broad, C. D. (1959). Five Types of Ethical Theory (New York: Littlefield, Adams and Co.).

Calhoun, Cheshire (2003). 'Cognitive Emotions?' in Solomon (2003).

Camus, Albert (2004). The Plague; The Fall; Exile and the Kingdom; and Selected Essays. Trans. Justin O'Brien (New York: Everyman's Library).

Chisholm, Roderick (1973). The Problem of the Criterion (Milwaukee: Marquette University Press).

Cholbi, Michael (2011). Suicide (Buffalo: Broadview Press).

Darwall, Stephen (2002). Welfare and Rational Care (Princeton: Princeton University Press).

De Sousa, Ronald (1999). The Rationality of the Emotions (Cambridge: MIT Press).

Dorsey, Dale (2011). 'The Hedonist's Dilemma', Journal of Moral Philosophy 8(2): 173-196.

Feagin, Susan (1983). 'The Pleasures of Tragedy', American Philosophical Quarterly 20(1): 95-104

Feldman, Fred (2006). Pleasure and the Good Life (Oxford: Oxford University Press).

Feldman, Fred (2012). 'What We Learn from the Experience Machine.', in Ralf M. Bader and John Meadowcroft (eds), The Cambridge Companion to Nozick's Anarchy, State, and Utopia (Cambridge: Cambridge University Press).

Fischer, John Martin (1993). The Metaphysics of Death (Stanford: Stanford University Press). 
Goldsworthy, Jeffrey (1992). 'Well-Being and Value.', Utilitas 4(1): 1-26.

Griffin, James (1986). 'Well-Being: Its Meaning, Measurement, and Moral Importance' (Oxford: Clarendon Press).

Haack, Susan (2002). 'Worthwhile Lives.', Free Inquiry 22(1): 50-51.

Haslett, D. W. (1990). 'What is Utility?', Economics and Philosophy 6: 65-94.

Haybron, Daniel M. (2010). The Pursuit of Unhappiness (Oxford: Oxford University Press).

Heathwood, Chris (2006). 'Desire Satisfactionism and Hedonism', Philosophical Studies 128: 539-563.

Heathwood, Chris (2008). 'Fitting Attitudes and Welfare', in Shafer-Landau (2008).

Heathwood, Chris (2011). 'Preferentism and Self-Sacrifice', Pacific Philosophical Quarterly 92: 18-38.

Helm, Bennett (2009). 'Emotions as Evaluative Feelings', Emotion Review 1: 248-255. Hooker, Brad (1996). 'Does Moral Virtue Constitute a Benefit to the Agent?', in Roger Crisp (ed.), How Should One Live? (Oxford: Oxford University Press).

Hume, D. (1985 [1757]). 'Of Tragedy', in D. Hume (ed.), Essays Moral, Political, and Literary (Indianapolis: Liberty Fund).

Hurka, Thomas (2001). Virtue, Vice, and Value (Oxford: Oxford University Press). Hurka, Thomas (2011). The Best Things in Life (Oxford: Oxford University Press). James, Williams (2003). 'What Is an Emotion?' in Solomon (2003).

Jaworska, Agnieszka (2007). 'Caring and Full Moral Standing', Ethics 117: $460-497$.

Kagan, Shelly (1992). 'The Limits of Well-Being', in E. F. Paul, F. D. Miller and Jeffrey Paul (eds), The Good Life and the Human Good (Cambridge: Cambridge University Press)

Kagan, Shelly (1994). 'Me and My Life', Proceedings of the Aristotelian Society 94: 309-324.

Kagan, Shelly (1998). Normative Ethics (Boulder: Westview Press).

Kagan, Shelly (2009). 'Well-Being as Enjoying the Good', Philosophical Perspectives 23, Ethics: 253-272.

Kawall, Jason (1999). 'The Experience Machine and Mental State Theories of Well-being', Journal of Value Inquiry 33: 381-387.

Kraut, Richard (2008). 'Two Concepts of Happiness.', in Steven M. Cahn and Christine Vitrano (eds), Happiness: Classic and Contemporary Readings in Philosophy (New York: Oxford University Press).

Levinson, Jerrold (1982). 'Music and Negative Emotions', Pacific Philosophical Quarterly 63: 327-346.

Levinson, Jerrold (1997). 'Emotion in Response to Art: A Survey of the Terrain', in Mette Hjort and Sue Laver (eds), Emotion and the Arts (Oxford: New York, 1997), 20-36.

Levinson, Jerrold (2004). 'Intrinsic Value and the Notion of a Life', Journal of Aesthetics and Art Criticism 62(4): 319-329.

Metz, Thaddeus (2002). 'Recent Work on the Meaning of Life', Ethics 112: 781-814.

Metz, Thaddeus (2007). 'New Developments in the Meaning of Life', Philosophy Compass 2(2): 197-217.

Mill, John Stuart (2002). Utilitarianism (Indianapolis: Hackett).

Moore, G. E. (2004). Principia Ethica (New York: Dover).
Morreall, John (1985). 'Enjoying Negative Emotions in Fictions', Philosophy and Literature 9(1): 95-103.

Nagel, Thomas (1993). 'Death', in Fischer (1993).

Neil, Alex (1992). 'On a Paradox of the Heart', Philosophical Studies 65: 53-65.

Neil, Alex (1996). 'Empathy and (Fiction) Film', in David Bordwell and Noël Carroll (eds), Post-Theory: Reconstructing Film Studies (Madison: University of Wisconsin Press).

Nozick, Robert (1974). Anarchy, State, and Utopia (New York: Basic Books).

Nozick, Robert (1989). 'Happiness', in The Examined Life (New York: Simon and Schuster).

Nozick, Robert (1997). 'On the Randian Argument', in Socratic Puzzles (Cambridge: Harvard University Press).

Nussbaum, Martha (1994). The Therapy of Desire: Theory and Practice in Hellenistic Ethics (Princeton: Princeton University Press).

Nussbaum, Martha (2001). Upheavals of Thought: The Intelligence of Emotions (Cambridge: Cambridge University Press).

Nussbaum, Martha (2003). 'Emotions as Judgments of Value and Importance', in Solomon (2003).

Oakley, Justin (1992). Morality and the Emotions (New York: Routledge).

Overvold, Mark (1980). 'Self-Interest and the Concept of Self-Sacrifice', Canadian Journal of Philosophy 10(1): 105-118.

Parfit, Derk (1984). Reasons and Persons (Oxford: Oxford University Press).

Price, Amy (1998). 'Nietzsche and the Paradox of Tragedy', British Journal of Aesthetics 38(4): 384-393.

Rawls, John (1971). A Theory of Justice (Cambridge: Harvard University Press).

Roberts, Robert C. (1988). 'What and Emotion Is: A Sketch', The Philosophical Review 97(2): 183-209.

Roberts, Robert C. (ed.) (2003). What Is an Emotion? (New York: Oxford University Press).

Ross, W. D. (1930). The Right and the Good (Indianapolis: Hackett).

Scanlon, Thomas (1993). 'Value, Desire, and the Quality of Life', in Martha Nussbaum and Amartya Sen (eds.), The Quality of Life (Oxford: Clarendon Press).

Scanlon, Thomas (1998). What We Owe to Each Other (Cambridge: Harvard University Press).

Shafer-Landau, Russ (ed.) (2008). Oxford Studies in Metaethics, vol. 3 (Oxford: Oxford University Press).

Shaw, Daniel (2007). 'Power, Horror, and Ambivalence', in Horror, special issue of Film and Philosophy.

Shoemaker, David (2003). 'Caring, Identification, Agency', Ethics 114: 88-118. Shoemaker, David (2011). 'Attributability, Answerability, and Accountability: Toward a Wider Theory of Moral Responsibility', Ethics 121: 602-632.

Smuts, Aaron (2007). 'The Paradox of Painful Art', Journal of Aesthetic Education 41(3): 59-77.

Smuts, Aaron (2009). 'Art and Negative Affect', Philosophy Compass 4(1): 39-55. Smuts, Aaron (2010). 'The Feels Good Theory of Pleasure', Philosophical Studies 155(2): 241-265. 
Smuts, Aaron (2011). 'Rubber Ring: Why Do We Listen to Sad Songs?' in John Gibson and Noël Carroll (eds), Narrative, Emotion, and Insight (Philadelphia: Penn State University Press).

Smuts, Aaron (circulating). 'Pleasurably Regarding the Pain of Fictional Others. Soll, Ivan (1998). 'On the Purported Insignificance of Death', in Jeff Malpas an Robert Solomon (eds), Death and Philosophy (New York: Routledge).

Solomon, Robert (1980). 'Emotions and Choice', in Amelie Oksenberg Rorty (ed.) Explaining Emotions (Berkeley: University of California Press).

Starkey, Charles (2008). 'Emotion and Full Understanding', Ethical Theory and Moral Practice 11: 425-454.

Stocker, Michael (1996). 'How Emotions Reveal Value and Help Cure the Schizophrenia of Modern Ethical Theory', in Roger Crisp (ed.), How Should One Live (Oxford: Oxford University Press).

Sumner, L. W. (1996). Welfare, Happiness, and Ethics (New York: Oxford University Press).

Tännsjö, Torbjörn (1998). Hedonistic Utilitarianism (Edinburgh: Edinburgh University Press)

Taylor, Charles (1985). 'Self-Interpreting Animals', in his Human Agency and Language, vol. 1 (New York: Cambridge University Press).

Trianosky, Gregory (1988). 'Rightly Ordered Appetites: How to Live Morally and Live Well', American Philosophical Quarterly 25(1): 1-12.

Trisel, Brooke Alan (2002). 'Futility and the Meaning of Life Debate', Sorites 14 $70-84$.

Trisel, Brooke Alan (2007). 'Judging Life and Its Value', Sorities 18: 60-75.

Williams, Bernard (1993). 'Morality and the Emotions', in his Problems of the Self (Cambridge: Cambridge University Press).

Wolf, Susan (1997). 'Happiness and Meaning: Two Aspects of the Good Life', Social Philosophy and Policy 14: 207-225.

Wolf, Susan (2010). Meaning in Life and Why it Matters (Princeton: Princeton University Press)

Wollheim, Richard (1984). The Thread of Life (New Haven: Yale University Press).

\section{That Obscure Object of Desire: Pleasure in Painful Art}

\section{Jonathan Gilmore}

EDGAR: O thou side-piercing sight!

KING LEAR: Nature's above art in that respect...

David Hume famously noted a puzzling aspect of our engagement with works of tragic drama:

It seems an unaccountable pleasure, which the spectators of a well-written tragedy receive from sorrow, terror, anxiety, and other passions, that are in themselves disagreeable and uneasy. The more they are touched and affected, the more are they delighted with the spectacle; and as soon as the uneasy passions cease to operate, the piece is at an end. ${ }^{1}$

What is puzzling is not that works such as tragedies seem to provoke both pleasure and pain, for many non-perplexing experiences do that. Nor is it odd that feeling pain may be necessary for feeling pleasure, for many ordinary circumstances have that structure. Rather, Hume's enigma is that our pleasure seems to be internally related to our distressing feelings. Feeling such pain is not a regrettable cost, but an essential element, of the pleasure in question, without which it would not be a desirable one. One would delight in blood-red sunsets even if they were not caused, as it happens, by aerosol pollution, but one would not derive certain pleasures from tragic dramas if they did not provoke their characteristic kinds of distress. ${ }^{2}$ As Hume notes, audiences are 'pleased in proportion as they are afflicted' ${ }^{3}$ Yet how best to describe this puzzle, beyond the noncommittal sketch above, remains contentious.

On the one hand, we often pursue and take pleasure or satisfaction in works of art in ways that are ostensibly explained by their elicitation 
Also by Jerrold Levinson

MUSIC, ART, AND METAPHYSICS

THE PLEASURES OF AESTHETICS

MUSIC IN THE MOMENT

CONTEMPLATING ART

AESTHETICS AND ETHICS (editor)

THE OXFORD HANDBOOK OF AESTHETICS (editor)

AESTHETIC CONCEPTS (co-editor with Emily Brady)

ART AND PORNOGRAPHY (co-editor with Hans Maes)

\section{Suffering Art Gladly}

The Paradox of Negative

Emotion in Art

Edited by

Jerrold Levinson

Department of Philosophy, University of Maryland, USA 